\title{
INFLUENCE OF pH ON THE PARTITION OF GLUCOSE-6-PHOSPHATE DEHYDROGENASE AND HEXOKINASE IN AQUEOUS TWO-PHASE SYSTEM
}

\author{
Daniel Pereira da Silva ${ }^{1}$; Marcela Zanella Ribeiro Pontes ${ }^{1}$; Maria Aparecida de Souza ${ }^{1}$; Michele Vitolo ${ }^{1}$; \\ João Batista de Almeida e Silva²; Adalberto Pessoa-Junior ${ }^{1 *}$
}

\author{
'Departamento de Tecnologia Bioquímico-Farmacêutica, Faculdade de Ciências Farmacêuticas, Universidade de São Paulo, São \\ Paulo, SP, Brasil; ${ }^{2}$ Departamento de Biotecnologia-FAENQUIL, Lorena, SP, Brasil
}

Submitted: February 21, 2001; Returned to authors for corrections: October 04, 2001; Approved: September 24, 2002

\begin{abstract}
Glucose-6-phosphate dehydrogenase (G6PDH) and hexokinase (HK) are important enzymes used in biochemical and medical studies and in several analytical methods. Aqueous two-phase system (ATPS) formed by a polymer solution and an electrolyte solution provides a method for the separation and purification of enzymes with several advantages, including biocompatibility and easy scale up of the process. In this work, the effects of different $\mathrm{pH}$ values on the storage stability and partitioning behavior $(\mathrm{K}$, partition coefficient) of the enzymes G6PDH and HK from baker's yeast extract were investigated in ATPS. The results, obtained from the 17.5\% PEG $400: 15.0 \%$ phosphate system, showed that when the $\mathrm{pH}$ was increased from 5.0 to 8.8 , the $\mathrm{K}_{\mathrm{HK}}$ increased 26-fold and the $\mathrm{K}_{\mathrm{G} 6 \mathrm{PDH}} 2.2$-fold. In the $20.0 \%$ PEG $1500: 17.5 \%$ phosphate system, the $\mathrm{K}_{\mathrm{HK}}$ and $\mathrm{K}_{\mathrm{G} 6 \mathrm{PDH}}$ increased 13 and 1.2-fold, when the $\mathrm{pH}$ value was increased from 3.8 to 8.8, respectively. This leads to the conclusion that the partition coefficient for both enzymes is favored by high pH values. A statistical analysis of the results was conducted to confirm this conclusion.
\end{abstract}

Key words: aqueous two-phase systems, partition coefficient, protein purification, hexokinase, glucose 6-phosphate dehydrogenase.

\section{INTRODUCTION}

Glucose-6-phosphate dehydrogenase (EC 1.1.1.49), the first enzyme of the pentose phosphate pathway, catalyzes the oxidation of glucose 6-phosphate (G6P) into 6-phosphogluconate. Hexokinase (EC 2.7.1.1), an important enzyme for the carbohydrate metabolism, is the first enzyme of glycolisis, catalyzes the phosphorylation of glucose into glucose 6phosphate (G6P), and is an intermediary between several metabolic pathways such as gluconeogenesis, shunt of pentoses, glycogen metabolism $(3,23)$.

HK and G6PDH enzymes, essential to the cell metabolism, are used in biochemical and medical studies, as analytical reagents to measure creatin-kinase activity as well as ATP and hexoses concentrations (3). Using these enzymes to measure glucose mixed with fructose allows one to detect illegal addition of sugar to the final product in wine and fruit juice industries, both highly developed in Brazil (25). However, industrial production of G6PDH and/or $\mathrm{HK}$ can only be viable if large quantities of these enzymes are available at competitive prices. Although these enzymes can be found in almost every animal tissue and in several microbial species, the use of S. cerevisiae as a source of enzymes (11) makes sense in Brazil, due to the large experience of the Brazilian chemical industry on handling this strain. Besides, the simultaneous processing of yeast and ethanol should have a positive effect on the profits of the distilleries.

The development of techniques and methods for the separation and purification of enzymes has been an indispensable prerequisite for many of the advances made in the biotechnological industry $(18,19)$. Aqueous two-phase

* Corresponding author. Mailing address: Departamento de Tecnologia Bioquímico-Farmacêutica, FCF - USP, Av. Prof. Lineu Prestes, 580, Bloco 16, Cidade Universitária, 05508-900, São Paulo, SP, Brasil. Tel.: (+5511) 3091-3862. Fax: (+5511) 3815-6386. E-mail: pessoajr@usp.br 
system (ATPS) formed by the addition of aqueous solutions of two polymers, such as PEG and dextran, or a polymer and an electrolyte solution, such as PEG and phosphate salt, is a method based on the partition of proteins between two liquid phases whose advantages include biocompatibility and possibility of application on industrial scale $(8,10)$. The partitioning in aqueous two-phase systems (ATPS) has proved to be an effective method for extraction and separation of soluble proteins from cell homogenates. These systems have important advantages over other techniques in their capacity and high activity yields at low labour, energy and capital cost, and handling of large volumes in a continuous process with relatively short contact times (13). Differences in enzyme partitioning can be ascribed to the interaction of the factors or mechanisms inherent in the system itself (such as choice of system components, polymer molecular weight, concentration of polymers and salts, ionic strength, and $\mathrm{pH}$ values) with those of the target protein (such as hydrophobicity, charge, and molecular weight) (15). According to Asenjo (2) the $\mathrm{pH}$ can alter the charge of chemical groups located in the side chain of protein amino acids leading to a net charge modification of the overall macromolecule, changing its solubility properties, at the end. Moreover, the enzyme can lose the catalytic capability either reversibly (precipitation at isoelectric $\mathrm{pH}$ ) or irreversibly (denaturation at $\mathrm{pH}$ values out of the stability $\mathrm{pH}$ interval) (15). Then the evaluation of the enzyme stability becomes indispensable, since during the downstream procedures it can be denaturated.

In practice, the technique of extraction in ATPS requires further experimentation to find an adequate system for each particular application (16). The aim of this work was to verify the effects of different $\mathrm{pH}$ values $(3.8,5.0,6.0,7.0,8.0$ and 8.8) on the partition coefficients $(\mathrm{K})$ of the enzymes G6PDH and HK in aqueous two-phase systems (17.5\% w/w PEG $400: 15.0 \%$ w/ w phosphate, and $20.0 \% \mathrm{w} / \mathrm{w}$ PEG $1500: 17.5 \% \mathrm{w} / \mathrm{w}$ phosphate). This work also deals with the effect of $\mathrm{pH}$ (4.0 to 9.5) on the storage stability of HK and G6PDH.

\section{MATERIALS AND METHODS}

\section{Chemicals}

Hexokinase (HK), glucose-6-phosphate dehydrogenase (G6PDH), adenosine triphosphate (ATP), nicotinamide adenine dinucleotide (NAD), nicotinamide adenine dinucleotide phosphate (NADP) and glucose 6-phosphate (G6P) utilized in the enzymatic analysis were obtained from Sigma Chemical Co. (St. Louis, USA). Poly(ethyleneglycol), samples with nominal molecular weights of 400 and $1500 \mathrm{~g} / \mathrm{mol}$ were purchased from Merck (Darmstadt, FRG). Sodium monohydrogen phosphate and potassium dihydrogen phosphate were purchase from CAAL (São Paulo, Brazil). All the other chemicals were of analytical grade.

\section{Cell Homogenate}

The cell homogenate, was prepared through disruption of commercial baker's yeast. The baker's yeast $(45 \mathrm{~g})$ was previously washed with $300 \mathrm{~mL}$ solution buffer (Tris-HCl $50 \mathrm{mM}$ ) $\mathrm{pH} 7.5$ and suspended in $50 \mathrm{~mL}$ of $50 \mathrm{mM}$ Tris- $\mathrm{HCl}$ buffer (pH 7.5) containing $5 \mathrm{mM} \mathrm{MgCl}, 10 \mathrm{mM} \beta$-mercaptoethanol, $2 \mathrm{mM}$ aminocaproic acid, $1 \mathrm{mM}$ PMSF (phenylmethylsulfonyl fluoride) and $0.2 \mathrm{mM}$ EDTA (ethylenediaminetetraacetic acid). Then, cells were disrupted with glass beads (diameter $=0.5 \mathrm{~mm}$ ). The mixture was maintained below $10^{\circ} \mathrm{C}$ all the time. The cell suspension (concentration of $250 \mathrm{~g} / \mathrm{L}$ ) and glass beads were mixed in a volumetric proportion of 1:1. After disruption, cell debris and glass beads were removed by filtration from the cell homogenate solution, which was then stored at $4^{\circ} \mathrm{C}$. Before the extraction in aqueous two-phase system, this cell homogenate was centrifuged ( $2880 \mathrm{~g}, 10 \mathrm{~min}$ ) and the supernatant containing G6PDH, HK and other enzymes were collected.

\section{Preparation of the storage solution}

The supernatant and an appropriate $0.1 \mathrm{M}$ buffer solution (acetic acid- acetate buffer $\mathrm{pH} 4.0,4.5,5.0$ or 5.5; phosphate buffer $\mathrm{pH}$ 6.0, 6.5 or 7.0 and Tris-HCl pH 7.5, 8.0, 8.5, 9.0 or 9.5) were mixed in a volumetric proportion of 1:9. In all tests the $\mathrm{pH}$ was checked after homogenizing the mixture. Samples of the storage solutions were taken for residual enzyme activity determination after $0,4 \mathrm{~h}, 8 \mathrm{~h}, 12 \mathrm{~h}, 24 \mathrm{~h}$ and $51 \mathrm{~h}$ of cell free extractbuffer contact.

\section{Aqueous Two-Phase Systems (ATPS)}

Systems were prepared with stock solutions: 50\% w/w PEG and $40 \% \mathrm{w} / \mathrm{w}$ phosphate salts (as monosodium and dipotassium mixture - $\mathrm{NaH}_{2} \mathrm{PO}_{4}$ and $\mathrm{K}_{2} \mathrm{HPO}_{4}$ ) utilizing deionized water. The systems were made up in the final concentration from $17.5 \% \mathrm{w} /$ w PEG $400: 15.0 \% \mathrm{w} / \mathrm{w}$ phosphate, and from $20.0 \% \mathrm{w} / \mathrm{w}$ PEG $1500: 17.5 \% \mathrm{w} / \mathrm{w}$ phosphate. In a graduated centrifuge tube $(15 \mathrm{~mL})$ two grams of the medium containing cell homogenate were mixed with PEG and phosphate solutions, the final ATPS component concentrations being adjusted with deionized water. The $\mathrm{pH}$ values of the systems were adjusted to 3.8, 5.0, 6.0, 7.0, 8.0 and 8.8 by varying the proportion between $\mathrm{NaH}_{2} \mathrm{PO}_{4}$ and $\mathrm{K}_{2} \mathrm{HPO}_{4}$ adequately. After that, the mixture was submitted to rotation ( $8 \mathrm{rpm}, 20 \mathrm{~min})$ followed by centrifugation $(1500 \mathrm{~g}$, $10 \mathrm{~min}$ ) and rest for $3 \mathrm{~h}$. During all the experiments the temperature was kept at about $4^{\circ} \mathrm{C}$. Samples of the top and bottom phases were then assayed to determine enzyme activities, total protein concentration, volumes and $\mathrm{pH}$ of the system phases.

\section{Enzyme Activities}

The G6PDH and HK activities were measured by spectrophotometry. The rate of increase in absorbance at 340 $\mathrm{nm}$ (caused by the increase in reduced $\mathrm{NADP}^{+}$as a function 
of time) was measured at $30^{\circ} \mathrm{C}$ and $\mathrm{pH} 7.5$, according to Bergmeyer (3). For both enzymes, one activity unit (U) was defined as the amount of enzyme catalyzing the reduction of $1 \mu \mathrm{mol}$ of $\mathrm{NADP}^{+}$per minute under the assay conditions. Enzyme activity degradation during storage of enzymes and accuracy of the determinations were checked in separate experiments.

\section{Protein Concentration}

The amount of total protein was determined according to the Coomassie Blue method described by Bradford (4), using bovine serum albumin (BSA) as standard.

\section{Partition coefficient $(\mathbf{K})$}

It was calculated by the ratio of the enzyme activity or the protein concentration in the top phase by the enzyme activity or protein concentration in the bottom phase. All determinations were performed in duplicate.

\section{RESULTS AND DISCUSSION}

Hexokinase (HK) and glucose-6-phosphate dehydrogenase (G6PDH) were extracted in the systems presented in Fig. 1. This Figure shows the partition coefficient (K), expressed as Log K, obtained for both enzymes $\left(\mathrm{K}_{\mathrm{HK}}\right.$ and $\mathrm{K}_{\mathrm{G} 6 \mathrm{PDH}}$ ), and total protein $\left(\mathrm{K}_{\text {TProt }}\right)$ as a function of $\mathrm{pH}$. It was observed that the best partition coefficients are obtained at higher $\mathrm{pH}$ values.

The increase in the partition coefficient as a function of $\mathrm{pH}$ has been observed for other proteins, like $\alpha$-amylase, taumatin, L-aspartase and fumarase $(5,12,20)$. According to these authors, the negatively charged protein should prefer the top phase of the aqueous two-phase system. This fact, probably explains the increase in the HK partition coefficient $\left(\mathrm{K}_{\mathrm{HK}}\right)$, as compared to the G6PDH partition coefficient $\left(\mathrm{K}_{\mathrm{G} 6 \mathrm{PDH}}\right)$, since the $\mathrm{G} 6 \mathrm{PDH}$ isoelectric point is approximately 6.5 and $\mathrm{HK}$ isoelectric point is 4.7-5.0 (6,26).

As can be seen in Fig. 1, the extractions performed with PEG 1500 provided lower partition coefficients, as compared to PEG 400 , independent on $\mathrm{pH}$ value, for both enzymes. But, extractions conducted with PEG 1500 are, particularly, promising, since the significant differences in partition between both enzymes can be used to selectively separate them. For all studied $\mathrm{pH}$ values, the enzyme HK goes, preferentially, to the top phase ( $\mathrm{K}$ value higher than 1), while G6PDH goes to the bottom phase (K value lower than 1).

The results, presented in Fig. 1, were statistically analyzed by the method described as Polynomial Regression Analysis, and are displayed in Fig. 2. The mathematical equation obtained for the system formed with PEG 400 showed that the relationship between the $\mathrm{K}_{\mathrm{HK}}$ and $\mathrm{pH}$ value was a third-order polynomial model (model A - Fig. 2-A). On the other hand, the mathematical model that describes the relationship between
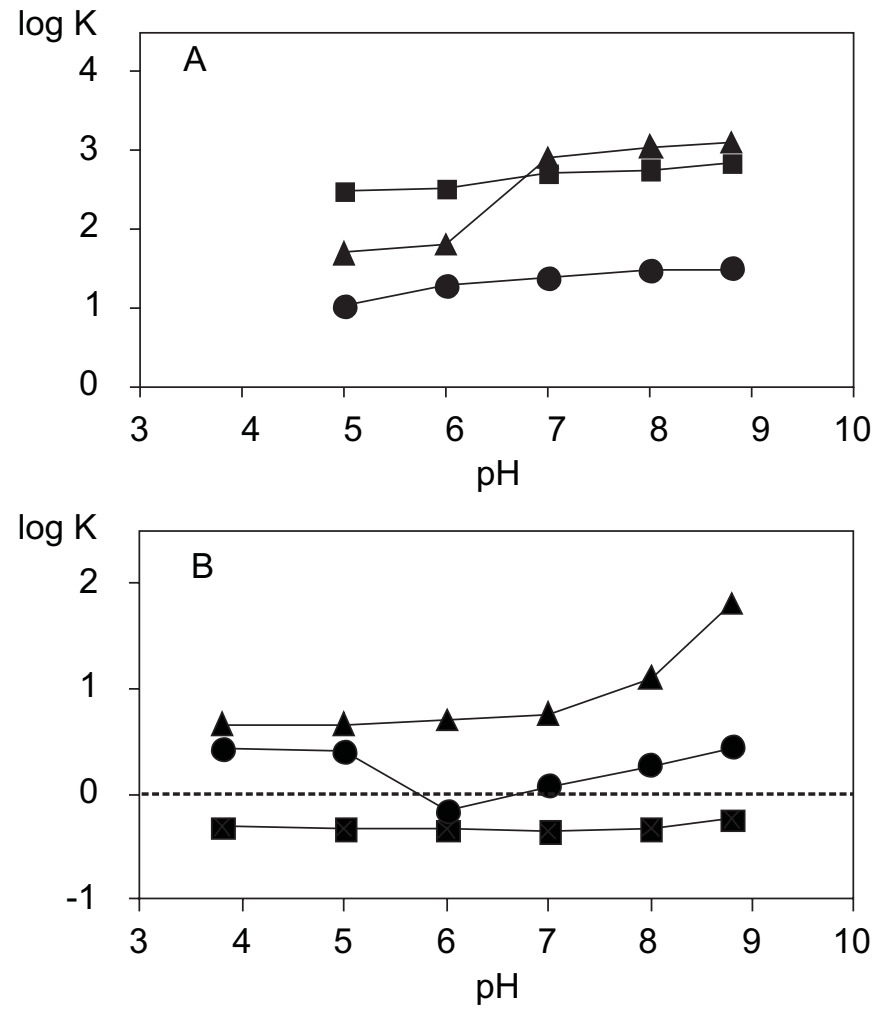

Figure 1. Effect of $\mathrm{pH}$ on the partitioning behavior $(\log \mathrm{K})$ of

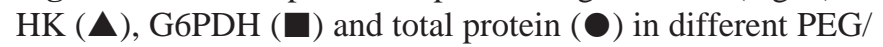
phosphate systems: $17.5 \%$ w/w PEG 400 with $15.0 \%$ w/w phosphate (A) and 20.0\% w/w PEG 1500 with $17.5 \%$ w/w phosphate (B).

$\mathrm{K}_{\mathrm{G} 6 \mathrm{PDH}}$ and $\mathrm{pH}$ value was polynomial of a first-order (model $\mathrm{B}$ Fig. 2-B). The system formed with PEG 1500, provided a fourthorder polynomial model to describe the relationship between the $\mathrm{K}_{\mathrm{HK}}$ and $\mathrm{pH}$ (Fig. 2-C). But, although the relationship between $\mathrm{K}_{\mathrm{G} 6 \mathrm{PDH}}$ and $\mathrm{pH}$ generated a model of second-order (Fig. 2-D), it can be seen that the $\mathrm{pH}$ did not influence the G6PDH partition coefficient. The Analysis of Variance of the results showed a P-value (probability value) less than 0.01 , for the models obtained for $\mathrm{K}_{\mathrm{HK}}$ and $\mathrm{K}_{\mathrm{G} G \mathrm{PDH}}$ in the system formed with PEG 400 (17.5\% w/w and $15.0 \% \mathrm{w} / \mathrm{w}$ phosphate) and for $\mathrm{K}_{\mathrm{HK}}$ in the system formed with PEG $1500(20.0 \%$ w/w with $7.5 \% \mathrm{w} / \mathrm{w}$ phosphate). This fact indicates a statistically significant relationship between partition coefficient and $\mathrm{pH}$ value, at $99 \%$ confidence level. But, for $\mathrm{K}_{\mathrm{G} 6 \mathrm{PDH}}$ in the system formed for PEG 1500 ( $20.0 \%$ w/w with $7.5 \% \mathrm{w} / \mathrm{w}$ phosphate) the P-value was greater than 0.10 , and was not statistically significant at $90 \%$ confidence level.

The $\mathrm{pH}$ values, determined after the partition of the phases (Table 1), varied for both PEG 400 and PEG 1500 during the extraction process. These variations can influence the 

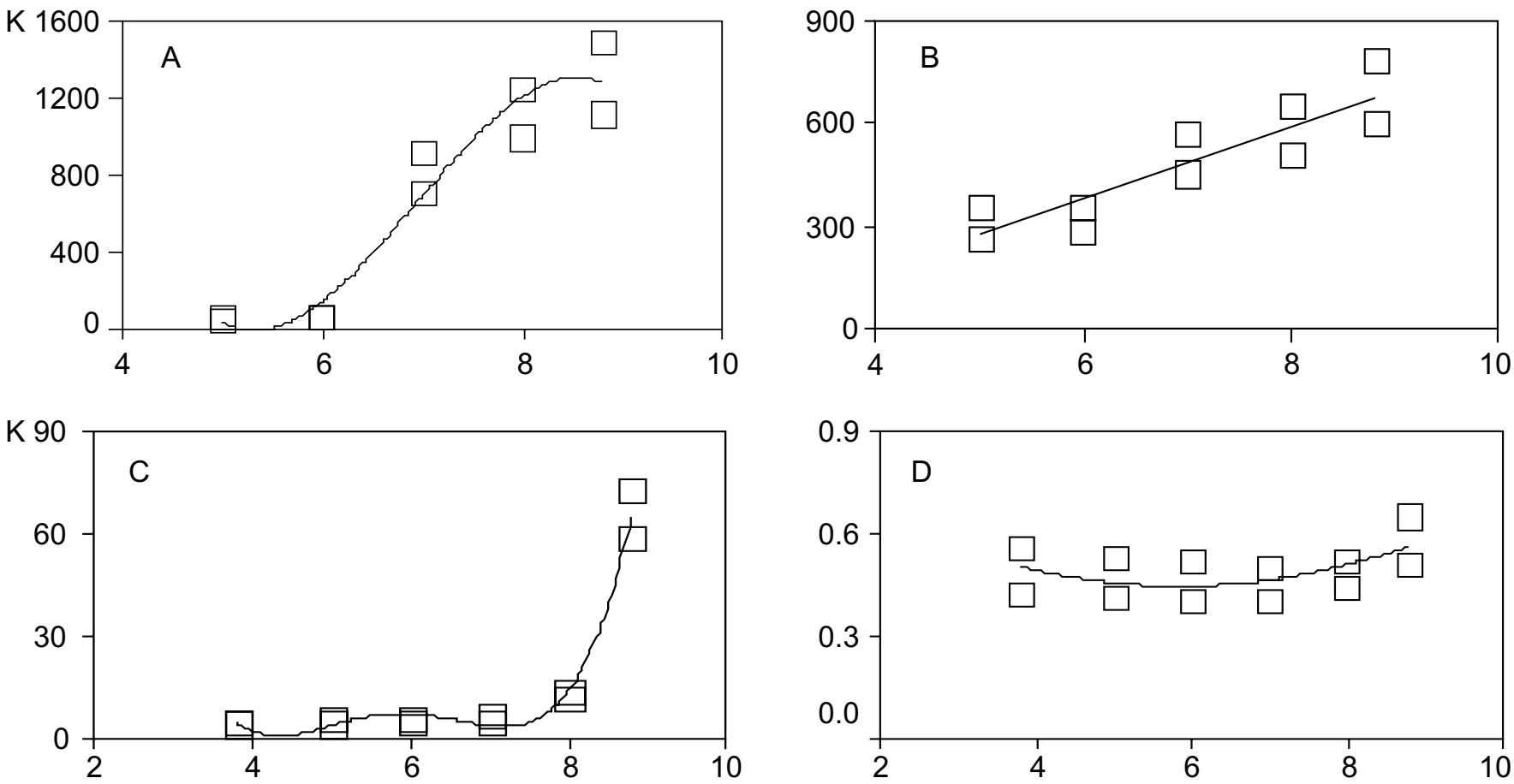

Figure 2. Effect of the $\mathrm{pH}$ on the partitioning coefficient (K) of HK (A and C) and G6PDH (B and D) in different PEG/phosphate systems: $17.5 \%$ w/w PEG 400 with $15.0 \%$ w/w phosphate (A and B) and 20.0\% w/w PEG 1500 with $17.5 \%$ w/w phosphate (C and D). The mathematical models that correlate $\mathrm{pH}$ value with partition coefficients $(\mathrm{K})$ are:
A - model (PEG 400, HK) $\mathrm{K}=22871.8-10852.2(\mathrm{pH})+1654.7(\mathrm{pH})^{2}-79.6(\mathrm{pH})^{3}$;
B - model (PEG 400, G6PDH) ......... K = - 256.3 + 106.1 (pH);
C - model $(\mathrm{PEG} 1500, \mathrm{HK}) \ldots \ldots \ldots \ldots . . \mathrm{K}=1199.5-883.4(\mathrm{pH})+238.9(\mathrm{pH})^{2}-28.1(\mathrm{pH})^{3}+1.2(\mathrm{pH})^{4}$;
D - model (PEG 1500, G6PDH) ....... K = 0,9-0.16(pH) +0.01(pH) .

Table 1. $\mathrm{pH}$ values of the phases after extractions obtained with different $\mathrm{pH}$ values.

\begin{tabular}{ccccc}
\hline & \multicolumn{2}{c}{$\begin{array}{c}17.5 \% \text { w } / w \\
\text { pH }\end{array}$} & $\begin{array}{c}\text { PEG 400 with } \\
\text { 15.0\% w/w phosphate }\end{array}$ & \multicolumn{2}{c}{$\begin{array}{r}\text { PEG } 1500 \text { with } \\
17.5 \% \text { w/w phosphate }\end{array}$} \\
\cline { 2 - 5 } & Top phase & $\begin{array}{c}\text { Bottom } \\
\text { phase }\end{array}$ & Top phase & $\begin{array}{c}\text { Bottom } \\
\text { phase }\end{array}$ \\
\hline 3.8 & NP & NP & 3.5 & 3.4 \\
5.0 & 5.4 & 5.2 & 4.6 & 4.5 \\
6.0 & 6.3 & 6.2 & 5.3 & 5.2 \\
7.0 & 7.1 & 7.0 & 6.1 & 6.1 \\
8.0 & 7.9 & 7.8 & 6.9 & 7.0 \\
8.8 & 8.7 & 8.7 & 7.3 & 7.6 \\
\hline
\end{tabular}

$\mathrm{NP}=$ no partition between the phases

enzymatic stability of the product, and so it is important to verify the interval of stability of the target enzyme, as follow. The data related to the stability of hexokinase and glucose-6phosphate dehydrogenase, after leaving the cell-free extract (supernatant) in buffer solutions at different $\mathrm{pH}$ by $51 \mathrm{~h}$ are presented in Fig. 3. As can be seen, both enzymes, present in the cell-free extract, were relatively stable (remaining activity $>80 \%$ ) at the beginning (about 5 hours) of the storage time at $\mathrm{pH}$ interval between 4.0 and 9.5. However, both enzymes were markedly unstable at $\mathrm{pH}$ 4.0. It can also be seen that the G6PDH is quite stable at $\mathrm{pH}$ interval from 5.0 to 9.5 , even after $51 \mathrm{~h}$ of buffer-enzyme contact. The hexokinase, in turn, was sensitive to $\mathrm{pH}$ values higher than 7.5. These results are quite similar to those found by Silva et al. (21) for the purified forms of HK (SIGMA ${ }^{\mathrm{R}}$-H5375) and G6PDH (SIGMA ${ }^{\mathrm{R}}$-G8529). Probably, the macromolecular structures of these proteins are well adapted to less acidic $\mathrm{pH}$ values, because the $\mathrm{pH}$ of the yeast cell cytoplasm, their natural location, is normally buffered at $\mathrm{pH}$ of 6.5-7.5 (24). Therefore, to avoid decrease in yield extraction, it is recommended to perform the extractions at $\mathrm{pH}$ values higher than 5.0 and lower than 9.5.

Another point to be borne out is that the best $\mathrm{pH}$ values for stability are higher than the correspondent isoelectric points of the enzymes, which are 4.8 and 6.0, respectively, for $\mathrm{HK}$ and G6PDH (6,26). Then, for $\mathrm{pH} \geq 6.5$ we can assume that the effective 

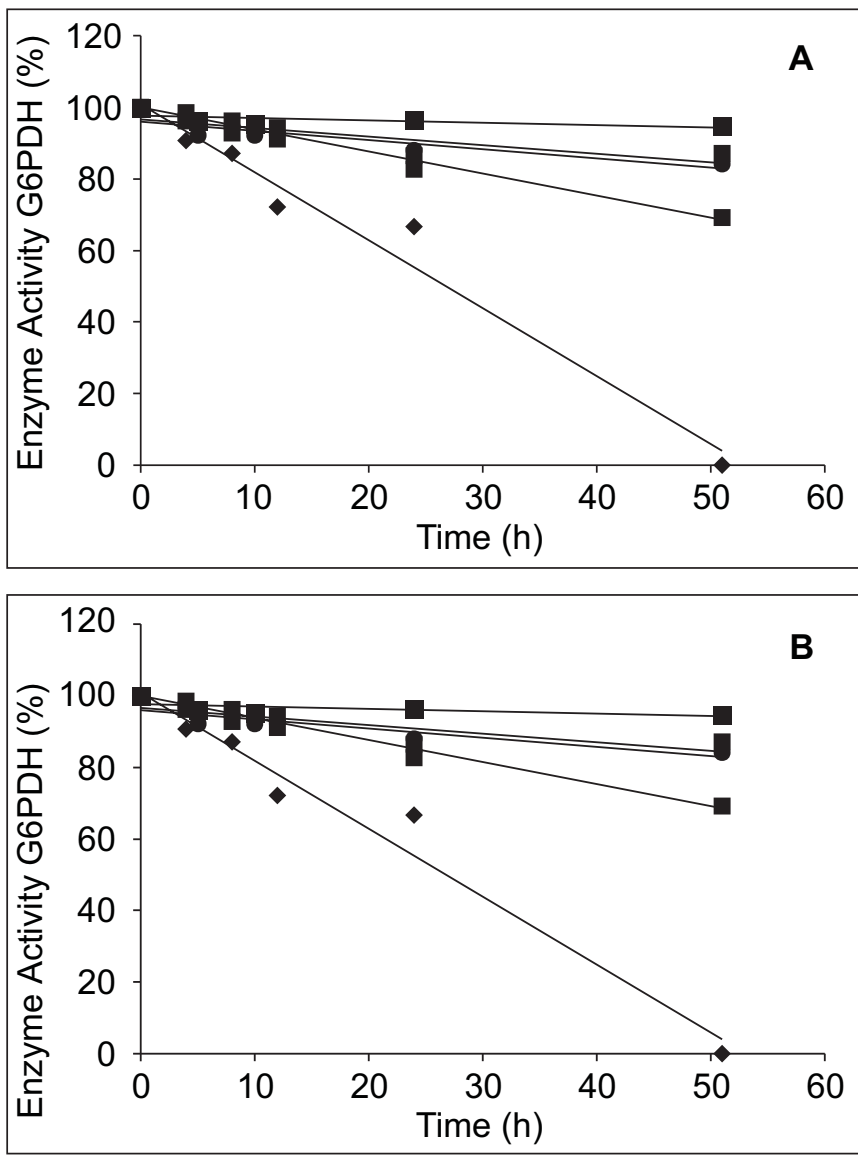

Figure 3. Remaining enzyme activities as function of $\mathrm{pH}$ and storage time at $4^{\circ} \mathrm{C}$. Enzyme G6PDH (Fig. 3-A): (3/4 “3/4 pH 4.0; $\left.3 / 4 \mathrm{n}^{3} / 4 \mathrm{pH} 4.5 ; 3 / 41^{3 / 4} \mathrm{pH} 5.0-5.5 ; 3 / 41^{3} / 4 \mathrm{pH} 6.0-6.5 ; 3 / 4 \mathbf{x}^{3} / 4 \mathrm{pH} 7.0-9.5\right)$. Enzyme HK (Fig. 3-B): $\left(3 / 4^{* 3} / 4 \mathrm{pH} 4.0 ; 3 / 4 \mathrm{n}^{3} / 4 \mathrm{pH} 4.5-5.5 ; 3 / 4 \mathrm{p}^{3} / 4 \mathrm{pH}\right.$ $\left.6.0-7.5 ; 3 / 4 \mathrm{p}^{3} / 4 \mathrm{pH} 8.0-8.5 ; 3 / 413 / 4 \mathrm{pH} 9.0-9.5\right)$.

electrical charge of both proteins is negative, a favorable condition for an extraction of HK and G6PDH from yeast cellfree extract through an aqueous two-phase system.

\section{CONCLUSIONS}

From a preliminary study it can be concluded that the partition coefficient strongly depends on the $\mathrm{pH}$ value, in other words, the enzymatic partition coefficient of the enzymes $\mathrm{HK}$ and G6PDH ( $\mathrm{K}_{\mathrm{HK}}$ and $\left.\mathrm{K}_{\mathrm{G} 6 \mathrm{PDH}}\right)$ was favored by high $\mathrm{pH}$ values. The statistical analysis indicated that only the model obtained for the partition coefficient of the enzyme glucose-6-phosphate dehydrogenase $\left(\mathrm{K}_{\mathrm{G} 6 \mathrm{PDH}}\right)$ was not significant at $90 \%$ or higher confidence level. Besides, during the extraction utilizing the system formed with PEG 1500 (20.0\% w/w) and phosphate salts $(17.5 \% \mathrm{w} / \mathrm{w})$, there is a possibility of partition between $\mathrm{HK}$ and G6PDH enzymes, and also between HK enzyme and other contaminant proteins. This is due to a significant difference in the partition coefficient values between $\mathrm{K}_{\mathrm{HK}}$ with $\mathrm{K}_{\mathrm{G} 6 \mathrm{PDH}}$ and $\mathrm{K}_{\text {Tprot}}$, when the $\mathrm{pH}$ value of the system is about 6.0. It is important to point out that the variations of the $\mathrm{pH}$ values during the extractions can denaturate both enzymes, and decrease the extraction yield.

\section{ACKNOWLEDGEMENTS}

We wish to thank Dr. José Abrahão-Neto for his valuable help with yeast homogenization, Maria Eunice M. Coelho for revision of this manuscript, and FAPESP and CNPq for sponsoring this research project.

\section{RESUMO}

\section{Influência do pH na partição da glicose 6-fosfato desidrogenase e hexoquinase em sistema de duas fases aquosas}

Glicose-6-fosfato desidrogenase (G6PDH) e hexoquinase (HK) são importantes enzimas usadas em estudos bioquímicos e médicos e em diversos métodos analíticos. Sistema de duas fases aquosas (SDFA) formado por uma solução polimérica e uma solução eletrolítica proporciona um método para separação e purificação de enzimas com diversas vantagens, incluindo biocompatibilidade, que pode ser facilmente escalonado para nível industrial. Neste trabalho, os efeitos de diferentes valores de pH na estabilidade e na partição ( $\mathrm{K}$, coeficiente de partição) por SDFA das enzimas G6PDH e HK, obtidas através de levedura de panificação, foram investigados. Os resultados, obtidos do sistema constituído por 17,5\% de PEG 400 e 15,0\% de fosfato, mostraram que com a elevação do $\mathrm{pH}$ de 5,0 para 8,8 , o $\mathrm{K}_{\mathrm{HK}}$ aumentou 26 vezes e o $\mathrm{K}_{\mathrm{G} 6 \mathrm{PDH}} 2,2$ vezes. No sistema $20,0 \%$ PEG $1500: 17,5 \%$ fosfato, quando o valor do $\mathrm{pH}$ variou de 3,8 para 8,8. os valores de $\mathrm{K}_{\mathrm{HK}}$ e $\mathrm{K}_{\mathrm{G} 6 \mathrm{PDH}}$ aumentaram e 13 vezes e 1,2 vez, respectivamente. Isto permite concluir que o coeficiente de partição, para ambas as enzimas, é favorecido pela elevação do pH. Uma análise estatística dos resultados foi conduzida para confirmar esta conclusão.

Palavras-chave: sistema de duas fases aquosas, coeficiente de partição, purificação de proteína, hexoquinase, glicose 6-fosfato desidrogenase.

\section{REFERENCES}

1. Albertsson, P.A.; Johansson, G.; Tjerneld, F. Aqueous two-phase separations. In: Asenjo, J.A. (ed). Separation Processes in Biotechnology. Marcel Dekker, New York, 1990.

2. Asenjo, J.A. Separation Processes in Biotechnology. Marcell Dekker Inc., New York, 1990.

3. Bergmeyer, H.U. Methods of Enzymatic Analysis. Wheinheim, v.2, 1983, 539p. 
4. Bradford, M.M. A rapid and sensitive method for the quantification of protein utilizing the principle of protein-dye binding. Anal. Biochem., 72: 248-254, 1976

5. Cascone, O.; Andrews, B.A.; Asenjo, J.A. Partitioning and purification of thaumatin in aqueous two-phase systems. Enz. Microb. Technol., 13: 629-635, 1991.

6. Chang, Y.K.; Chase, H.A. Ion exchange purification of G6PDH from unclarified yeast cell homogenates using expanded bed adsorption. Biotechnol. Bioeng., 49(2): 204-216, 1996.

7. Chang, Y.K.; Chase, H.A. Ion exchange purification of G6PDH from yeast cell homogenates using expanded bed adsorption. Biotechnol. Bioeng., 49: 204-216, 1996.

8. Costa, S.A.; Pessoa-Junior, A.; Roberto, I.C. Xylanase recovery: effect of extraction conditions on the aqueous two-phase systems using experimental design. Appl. Biochem. Biotechnol., 70/72: 629639, 1998.

9. Frey, S.D.; Elliott, E.T.; Paustian, K. Application of the hexokinase glucose-6-phosphate desidrogenase enzymatic assay for measurement of glucose in amended soil. Soil Biol. Biochem., 31: 933-935, 1999

10. Gaikar, G.V.; Bodhankar, S.S.; Latha, V.J. J. Chem. Technol. Biotechnol., 67: 329-332, 1996.

11. Godfrey, T.; West, S. Industrial Enzymology. MacMillan Press, London, 1996.

12. Huddleston, J.G.; Ottomar, K.W.; Ngonyani, D.M.; Lyddiatt, A. Influence of system and molecular parameters upon fractionation of intracellular proteins from Saccharomyces by aqueous two-phase partition. Enz. Microb. Technol., 13: 24-32, 1991.

13. Huenupi, E.; Gomez, A.; Andrews, B.A.; Asenjo, J.A. Optimization and design considerations of two-phase continuous protein separation. J. Chem. Tech. Biotechnol., 74: 256-263, 1999.

14. Lahore, H.M.F.; Miranda, M.V.; Fraile, E.; Bonino, M.J.B.J.; Cascone O. Partition behavior and purification of a Mucor bacilliformis acid protease in aqueous two-phase systems. Proc. Biochem., 30: 615$621,1995$.

15. Lehninger, A.L.; Nelson, D.L.; COX, M.M. Principles of Biochemistry, $2^{\text {nd }}$ Edition.Worth Publishers, New York, 1993.
16. Pessoa-Junior, A.; Vitolo, M. Xylanase Recovery: Downstream processing of inulinase: comparison of different techniques. Appl. Biochem. Biotechnol., 70/72: 505-511, 1998.

17. Ricci-Silva, M.E. Estudo da influência de diferentes fontes de nitrogênio no meio de cultivo visando à obtenção de hexoquinase e glicose 6-fosfato desidrogenase em S. cerevisiae. São Paulo, 1998, 85p. (Dissertação de Mestrado. Faculdade de Ciências Farmacêuticas. USP).

18. Rodrigues, E.M.G.; Milagres, A.M.F.; Pessoa-Junior, A. Proc. Biochem., 34: 121-125, 1999b.

19. Rodrigues, E.M.G.; Pessoa Junior, A.; Milagres, A.M.F. Appl. Biochem. Biotechnol., 77/79: 779-788, 1999a.

20. Schmidt, A.S.; Ventom, A.M.; Asenjo, J.A. Partitioning and purification of a-amylase in aqueous two-phase systems. Enzyme Microb. Technol., 16: 131-142, 1994.

21. Silva, D.P.; Pessoa-Junior, A.; Vitolo, M. Partition of Hexokinase and Glucose-6-Phosphate Dehydrogenase in an Aqueous Two-Phase System: Influence of Polyethylene Glycol Molecular-Weight. Bollettino Chimico Farmaceutico, 138(2): 48, 1999

22. Silva, D.P.; Pessoa-Junior, A.; Vitolo, M. Effect of temperature and $\mathrm{pH}$ on storage stability of hexokinase and glucose-6-phosphate dehydrogenase. I Bolletino Chimico Farmaceutico - Rivista di Science Farmaceutiche e Biologiche, 138: XLVIII, 1999.

23. Stryer, L. Bioquímica. Guanabara Koogan, Rio de Janeiro, 1992 $881 \mathrm{p}$.

24. Thevelein, J.M.; Beullens, M.; Honshoven, F.; Hoebeeck, G.; Detremerie, K.; Hollander, J.A.; Jans, A.H. Regulation of the camp level in the yeast Saccharomyces cerevisiae intracellular $\mathrm{pH}$ and the effect of membrane depolarizing compounds. J. Gen. Microbiol., 133: 2191-2196, 1987.

25. Whitaker, J.R. Enzymes in Analytical Chemistry. In: FOX, P.F. (ed). Food Enzymology. Elsevier Science Publishers, New York, v.2, 1991.

26. Wolberg, R.B.G.; Hilhorst, R.; Voskiilen, G.; Nachtegaal, H.; Dekker, M.; Van't Riet, K.; Bijsterbosch, B.H. Protein Transfer from an Aqueous Phase into Reversed Micelles. The effect of Protein Size and Charge Distribution. European J. Biochem., 184: 627-633, 1989. 